\title{
Effect of Macrolide Antibiotics on Neutrophil Function in Human Peripheral Blood
}

\author{
Eiichiro SUGIHARA \\ First Department of Internal Medicine, Kurume University School of Medicine \\ (Received: Junuary 14, 1997 \\ (Accepted: Junuary 27, 1997) \\ Key words: neutrophil, superoxide, chemotaxis, macrolide antibiotics, \\ diffuse panbronchiolitis
}

\begin{abstract}
Since "small-dose and long-term" administration of erythromycin (EM) was shown to be efficacious in the treatment of chronic respiratory disease, the modulation of host defense responses by EM has attracted much attention. Although there is considerable controversy, it was recently demonstrated that EM activity reduces neutrophil function.

In this study, we investigated the in vitro effects of the macrolides erythromycin (EM), a 14-membered ring, azithromycin (AZM), a 15-membered ring and rokitamycin (RKM), a 16-membered ring macrolide, on neutrophil function. The DCFH-DA method and cytochrome $\mathrm{C}$ method were used for assay of active oxygen generation and the Boyden-chamber method was used for assay of chemotaxis. EM and AZM, both of which have been shown to be clinically effective in the treatment of Diffuse panbronchiolitis (DPB), significantly suppressed active oxygen generation and chemotaxis of neutrophils at low concentrations equivalent to therapeutic doses $(0.5 \sim 1.0 \mu \mathrm{g} / \mathrm{ml}, \mathrm{p}<0.05)$, whereas the clinically ineffective RKM did not. The in vitro inhibitory effects of EM and AZM on active oxygen generation and chemotaxis of neutrophils demonstrated in the present study may be responsible for the therapeutic efficacy of these 14-membred and 15-membered ring macrolides in the treatment of DPB patients.
\end{abstract}

\section{Introduction}

Recently, clinical evidence in support of the therapeutic efficacy of macrolide antibiotics in treatment of chronic and. refractory lower respiratory tract diseases has been accumulating ${ }^{1)}$, although the mechanisms involved remain unknown. It is well known that the antimicrobial activity of erythromycin (EM), a representative macrolide, is not potent enough, and that the concentrations that can be achieved at the infectious lesions are not high enough to eliminate the majority of the causative bacterial species in acute infectious exacerbations or chronic insidious infection in the bronchioles. therefore, the clinically proven efficacy of EM in treatment of disease is considered to be due to its immunomodulatory rather than antimicrobial activity. DPB is a disease characterized by marked neutrophil accumulation ${ }^{2}$ and excess mucus production in the bronchioles. Neutrophils, which migrate to and are activated at the infectious site, act to protect the tissues from destruction by killing and by eliminating the causative organisms. Neutrophils which accumulate in excess and remain in lesions for long periods in an activated state, however, are often hazardous to the tissues because of the production and release of toxic factor such as active oxygen molecules ${ }^{3)}$ and lytic

Correspondence to : Eiichiro SUGIHARA, M.D.

First Department of Internal Medicine, Kurume University School of Medicine, 67, Kurume-city Asahimach 
enzymes $^{4}$. Thus, neutrophils may play a crucial role in the pathogenesis of DPB. To elucidate the mode of action through which EM exerts its efficacy in the treatment of DPB, we examined the in vitro effects of EM, a 14-membered ring macrolide and of azithromycin (AZM), a 15-membered ring macrolide, on active oxygen production and neutrophil chemotaxis in comparison with that of rokitamycin (RKM), a 16-membered ring macrolide which has been shown to be clinically ineffective in the treatment of DPB.

\section{Materials and Methods}

1) Preparation of macrolide solutions

Erythromycin (EM; product of Wako Pure Chemicals Co.), azithromycin (AZM: Pfizer Pharmaceutical Co.) and rokitamycin (RKM; Asahi chemical Co.) are 14-membered, a 15-membered and 16 -membered ring macrolides, respectively. Four mg of each drug was dissolved in $1.0 \mathrm{ml}$ of $99.5 \%$ ethanol and stored at $-20^{\circ} \mathrm{C}$ until use. The stock solution was diluted with phosphate buffered saline $\mathrm{pH} 7.4$ to make final concentrations of $0.05,0.1,0.5,1.0,10.0$, and $20.0 \mu \mathrm{g} / \mathrm{ml}$. The final concentration of the solvent $99.5 \%$ alcohol used in the reaction mixture was adjusted to less than $1 \%$ so that it would not affect the reaction.

2) Preparation of neutrophils

Neutrophils were separated from the heparinized peripheral blood of healthy volunteers. Briefly, after the dextran sedimentation of whole blood, erythrocyte were removed by hypotonic lysis. Neutrophils were obtained by Ficoll-Conray gradient centrifugation and washed twice with phosphate buffered saline, $\mathrm{pH} 7.4$. The cells were suspended in the buffer to make a suspension of $2 \times 10^{6}$ cells/ $\mathrm{ml}$.

3) Assay of reactive oxygen production by neutrophils

1. Dichlorofluorescin diacetate (DCFH-DA) method.

A partially modified method of Bass and colleagues ${ }^{5)}$ was employed. EM, AZM and RKM solutions were added to whole blood samples to make final concentrations ranging from 0.05 to 20.0 $\mu \mathrm{g} / \mathrm{ml}$. Blood samples, to which diluted solvent alone was added, served as controls. Two ml of $5 \mu \mathrm{M}$ dichlorofluorescin diacetate (DCFH-DA: Kodak) was then added to the mixtures. Immediately after shaking at $37^{\circ} \mathrm{C}$ for $15 \mathrm{~min}$, the mixtures were cooled in ice water. Aliquots of $0.5 \mathrm{ml}$ of $25 \mathrm{mM}$ EDTA solution in phosphate buffered saline and $10 \mu \mathrm{l}$ of $25 \mu \mathrm{g} / \mathrm{ml}$ phorbol 12-myristate 13-acetate (PMA; Sigma) were added successively. After shaking for $20 \mathrm{~min}$ at $37^{\circ} \mathrm{C}$, the mixtures were cooled again in ice water. Erythrocytes were lysed by adding $0.87 \% \mathrm{NH}_{4} \mathrm{Cl}$ lysis solution and were removed by centrifugation for $10 \mathrm{~min}$ at $1200 \mathrm{rpm}$ at $4^{\circ} \mathrm{C}$. The resulting pellets were suspended in $0.6 \mathrm{ml}$ of 2.5 $\mathrm{mM}$ EDTA solution in PBS. Dichlorofluorescin diacetate (DCFH-DA), a stable nonfluorescent compound, penetrates into the cells and be descacetylated by cytosolic enzymes to give a compound, $2^{\prime} 7^{\prime}$-dichlorofluorescin (DCFH), that is nonfluorescent and stable for a few hours. DCFH is rapidly oxidized to highly flourescent $2^{\prime} 7^{\prime}$-dichlorofluorescein (DCF) in the presence of hydrogen peroxide. In the present study, the fluorescence intensity of DCF thus formed in individual neutrophils was recored using a flow cytometer (FACScan; Becton Dickinson) at a wave length of $488 \mathrm{~nm}$ with an argon laser and the results were analyzed by Consort 30 software. From the histogram delineated by gaiting the neutrophil region, the mean DCF fluorescence per individual neutrophil cell was calculted, and expressed as the amount of active oxygen produced by a single cell.

2. Cytochrome $\mathrm{C}$ method.

Neutrophils were isolated from heparinized peripheral blood obtained from a healthy volunteer. To the suspensions of neutrophils, EM, AZM or RKM was added to make final concentrations of 0.05 , $0.1,0.5,1.0,10.0$ and $20 \mu \mathrm{g} / \mathrm{ml}$. Suspension to which only solvent (ethanol) was added served as a 
control. Then $40 \mu \mathrm{l}$ of $12.5 \mathrm{mg} / \mathrm{ml}$ of cytochrome C (Wako pure chemical), and $100 \mu \mathrm{g}$ of $2 \mu \mathrm{g} / \mathrm{ml}$ of PMA were added to the neutrophil suspensions and the volume of the reaction mixture was adjusted to $1.0 \mathrm{ml}$ by the addition of PBS. Reduction of cytochrome $\mathrm{C}$ during incubation of the reaction mixtures at $37^{\circ} \mathrm{C}$ was measured by recording optical density at $550 \mathrm{~nm}$ using a spectrophotometer (Hitachi 220A), and the amounts of active oxygen formed were calculated.

4) Assay of neutrophil chemotaxis.

Neutrophil chemotaxis was assayed by a modified Boyden method using a polycarbonate filter with a $3 \mu \mathrm{m}$ pore size. Twenty-five $\mu 1$ of $10^{-7} \mathrm{M}$ N-formyl Met-Leu-Phe (FMLP; Sigma) was poured into the lower chamber and $50 \mu 1$ of each of the neutrophil suspensions, which were pretreated with eighte EM, AZM or RKM at various concentrations ranging from 0.05 to $20.0 \mu \mathrm{g} / \mathrm{ml}$, were poured into the upper chamber. The chamber was incubated for one hour at $37^{\circ} \mathrm{C}$ under $5 \% \mathrm{CO}_{2}$ in humidified air. Then the chamber filter was removed and stained with May-Giemsa stain after washing with PBS three times. The cells which had migrated through the membrane filter to the other side were counted in a microscopic high power field $(\times 400)$. Neutrophil chemotactic activity (NCA) was expressed as the mean number of migrated cells.

5) Viability of neutrophils.

The number of neutrophils which were not stained with Trypan blue dye after the centrifugation at $4^{\circ} \mathrm{C}$ either at $1600 \mathrm{rpm}$ for $30 \mathrm{~min}$ or at $1000 \mathrm{rpm}$ for $6 \mathrm{~min}$, was counted using Neubauer's counting chamber. Viability was expressed as the percentage of neutrophils which were not stained with the dye.

6) Statistical analysis.

All values were expressed as mean \pm SE. Paired student's t test was used for the comparison of two groups.

\section{Results}

1) Effect of EM on generation of active oxygen by neutrophils.

a) DCFH-DA method

Fig. 1 shows the active oxygen generation of neutrophils determined by the DCFH-DA method and the effect of EM on this activity. The mean fluorescence intensity (mean amount of DCF produced) per individual neutrophil in the abscence of EM was $1521.7 \pm 200.5$. The activity was significantly suppressed by EM at both low concentrations $(967.5 \pm 87.4$ at $0.1 \mu \mathrm{g} / \mathrm{ml}$ and $859.9 \pm$

Fig. 1 Effect of EM on active oxygen generation by neutrophils determined by the DCFH-DA method. ${ }^{*} \mathrm{p}<0.05$ compared with control.

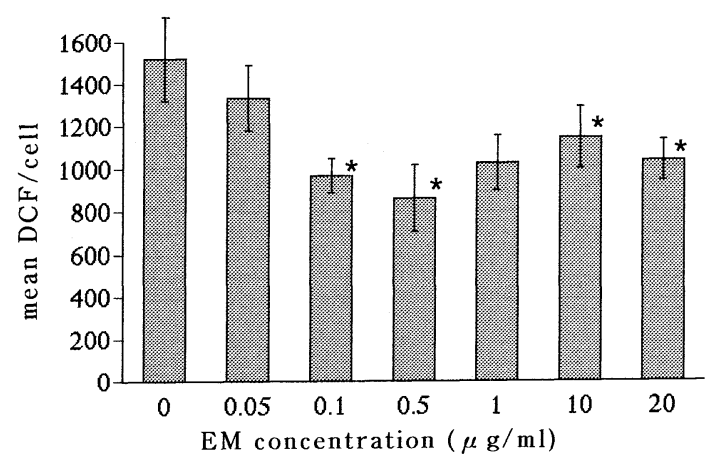

Fig. 2 Effect of EM on active oxygen generation by neutrophils determined by the cytochrome $\mathrm{C}$ method. ${ }^{*} \mathrm{p}<0.05$ compared with control.

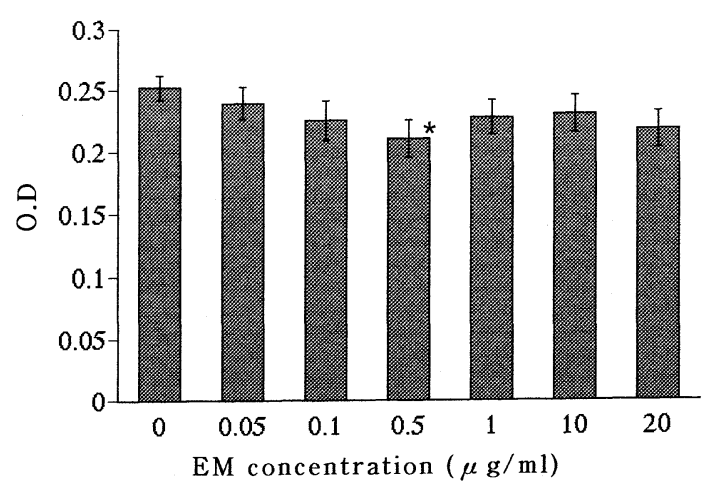


155.9 at $0.5 \mu \mathrm{g} / \mathrm{ml}, \mathrm{p}<0.05$ for both) and higher concentrations $(1143.0 \pm 144.7$ at $10 \mu \mathrm{g} / \mathrm{ml}$ and $1036.4 \pm 99.5$ at $20.0 \mu \mathrm{g} / \mathrm{ml}, \mathrm{p}<0.05$ for both).

b) Cytochrome $\mathrm{C}$ method

As shown in Fig. 2, the suppression of active oxygen generation by EM was not as marked when determined by the cytochrome $\mathrm{C}$ method as compared to that determined by the DCFH-DA method. Specifically, significant suppression $(\mathrm{p}<0.05)$ was demonstrated only when EM was present at a concentration of $0.5 \mu \mathrm{g} / \mathrm{ml}(0.252 \pm 0.010$ O.D. at $550 \mathrm{~nm}$ and $0 \mu \mathrm{g} / \mathrm{ml}$ vs $0.211 \pm 0.015$ at $0.5 \mu \mathrm{g} /$ $\mathrm{ml})$.

2) Effects of AZM and RKM on generation of active oxygen by neutrophils.

When determined by DCFH-DA method, AZM was found to significantly suppress active oxygen generation by neutrophils at a wider range of concentrations, ranging from 0.1 to $20.0 \mu \mathrm{g} / \mathrm{ml}$ (Fig. 3), than with EM. The suppression peaked at a concentration of $0.5 \mu \mathrm{g} / \mathrm{ml}$. When determined by the cytochrome $\mathrm{C}$ method, again lower levels of suppression than with the DCFH-DA method was seen. The suppression was significant only at a lower concentration $(0.5 \mu \mathrm{g} / \mathrm{ml}, \mathrm{p}<0.01)$ and higher concentration $(20 \mu \mathrm{g} / \mathrm{ml}, \mathrm{p}<0.05)$ (Fig. 4). A similar pattern of suppression was observed when the neutrophils were treated with RKM. The suppression of active oxygen generation by RKM, however,

Fig. 3 Effect of AZM on active oxygen generation by neutrophils determined by the DCFH-DA method. ${ }^{*} \mathrm{p}<0.05,{ }^{* *} \mathrm{p}<0.01$, compared with control.

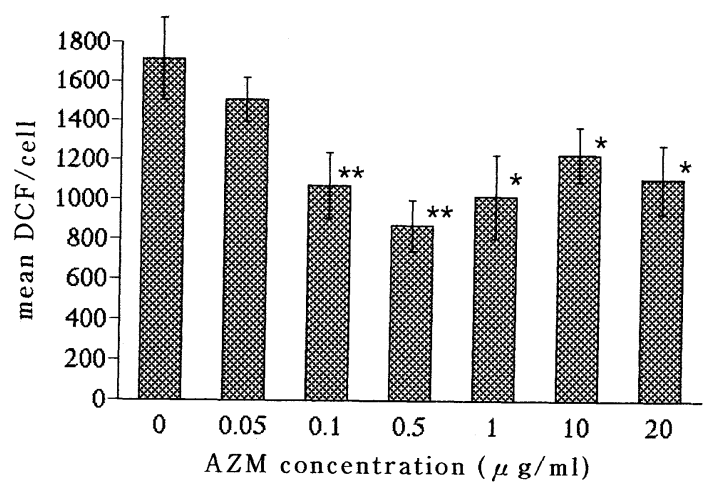

Fig 5 Effect of RKM on active oxygen generation by neutrophils determined by the DCFH-DA method.

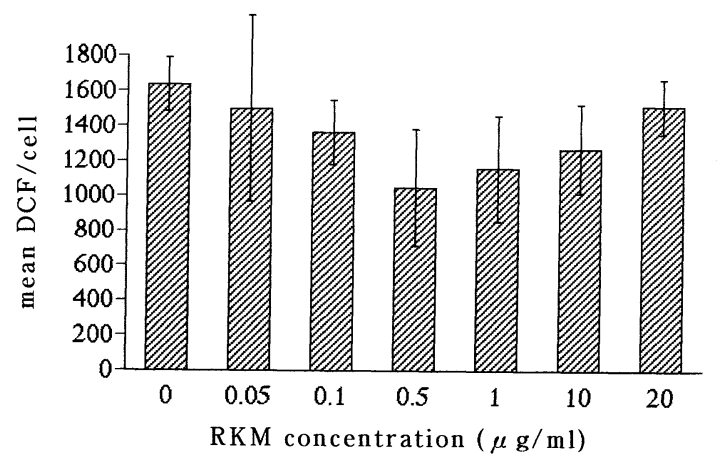

Fig. 4 Effect of AZM on active oxygen generation by neutrophils determined by the cytochrome $\mathrm{C}$ and method. ${ }^{*} \mathrm{p}<0.05,{ }^{* *} \mathrm{p}<0.01$ compared with control.

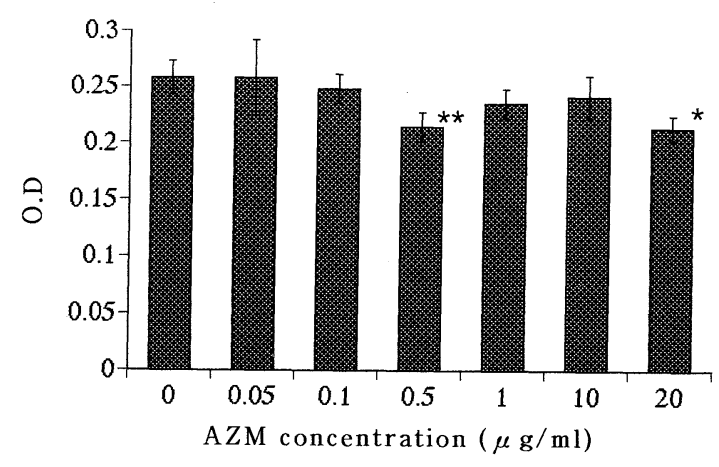

Fig. 6 Effect of RKM on active oxygen generation by neutrophils determined by the cytochrome $\mathrm{C}$ method.

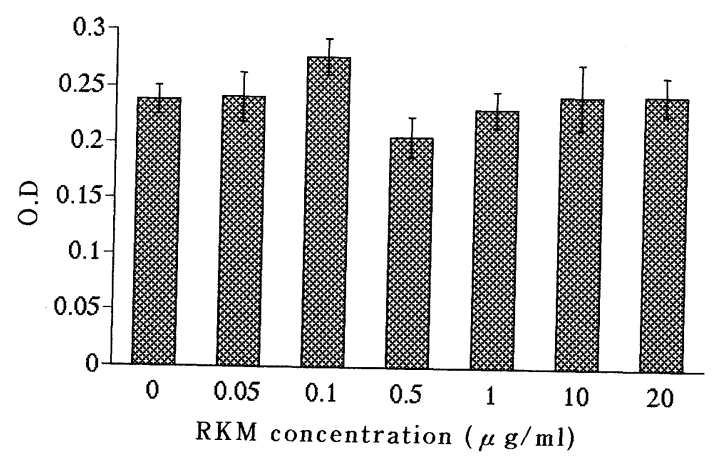

感染症学雑誌 第71巻 第 4 号 
Fig. 7 Effect of EM on neutrophil chemotaxis**. $\mathrm{p}<0.01$ compared with control.

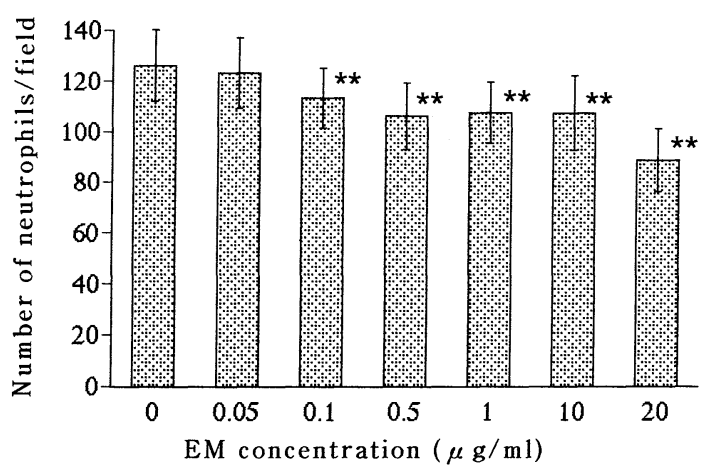

Fig. 9 Effect of RKM on neutrophil chemotaxis**. $\mathrm{p}<0.01$ compared with control.

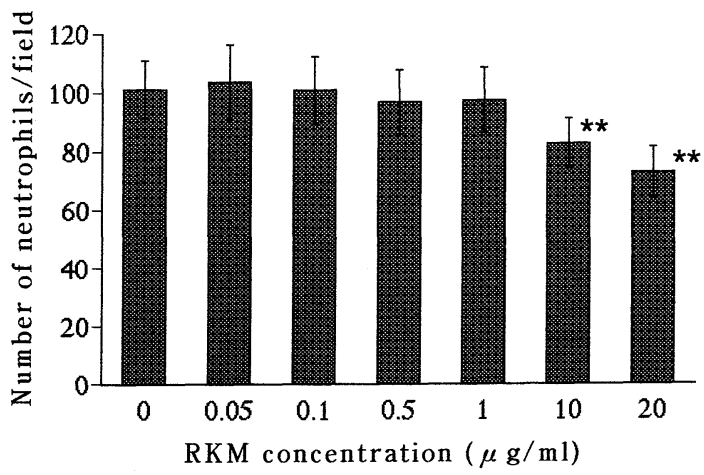

Fig. 8 Effect of AZM on neutrophil chemotaxis**. $\mathrm{p}<.01$ compared with control.

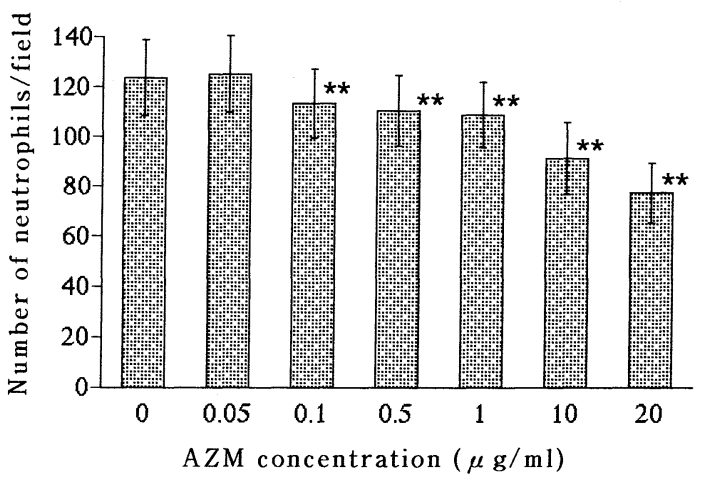

Fig. 10 Comparison of neutrophil viability between the neutrophil-sources employed for the determination of active oxygen generation* and chemotaxis**.

DCFH-DA method used whole blood as the neutrophil source,while the cytochrome $\mathrm{C}$ and Boyden-chamber methods both used purified neutrophil preparations.

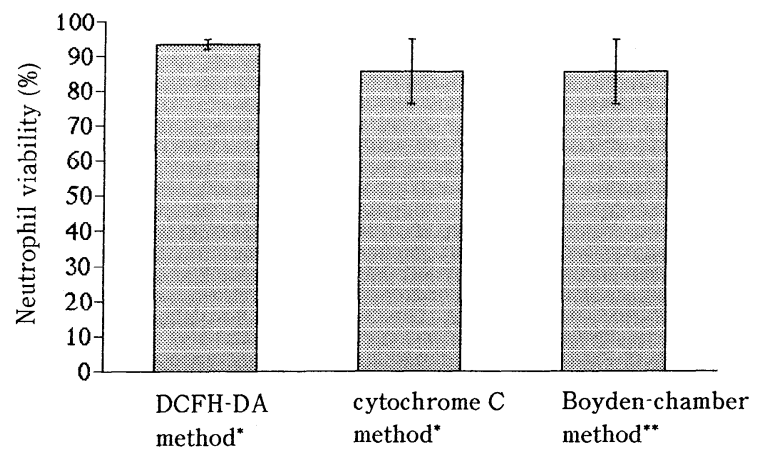

was not significant at any concentration tested regardless of the assay method (Fig. 5 and 6).

3) Effects of EM and AZM on neutrophil chemotaxis.

As shown in Fig. 7 and 8, both EM and AZM suppressed neutrophil chemotaxis significantly ( $<<$ 0.01 ), at concentrations of $0.1 \mu \mathrm{g} / \mathrm{ml}$ and above. The inhibition of migration by both EM and AZM became more prominent as the concentration increased, and the level of inhibition was highest with both drugs at the highest concentration tested; $20.0 \mu \mathrm{g} / \mathrm{ml}$. RKM, which was shown to suppress active oxygen generation slightly but not significantly, also suppressed neutrophil chemotaxis, but only at the higher concentrations of 10.0 and $20.0 \mu \mathrm{g} / \mathrm{ml}$ (Fig. 9).

4) Viability of neutrophil cells in the sample.

The percentage of viable neutrophil cells decreased from $93.2 \pm 1.4$ in the whole blood samples, which were used for determinations of active oxygen generation by cytochrome $\mathrm{C}$ method and of migration by Boyden-chamber method, to $86.5 \pm 9.3$ in the neutrophil samples, which were partially purified by dextran sedimentation and by Ficoll-Conray gradient centrifugation and used for the 
determination of active oxygen generation by the DCFH-DA method.

\section{Discussion}

Diffuse panbronchiolitis (DPB) has been recognized as a pulmonary disease which is extremely refractory to a wide variety of therapeutic modalities and has a poor prognosis. Introduction and clinical application of a "small-dose and long-term" erythromycin (EM) therapy, however, has converted the prognosis of this disease to a markedly favorable one ${ }^{1)}$. Accordingly, the treatment of DPB patients with EM has now become a standard therapy, although the mode of action still remains unknown. Meanwhile, remarkable increase in both count and percentage of neutrophils in bronchoalveolar lavage fluids (BALFs) from DPB patients have been shown to be normalized by EM treatment, in association with an apparent reduction in elastolytic-like activity ${ }^{2,4,7)}$. These clinical and in vitro observations strongly suggested that the agent might alter the function of neutrophils which had migrated to and accumulated in the bronchioles of DPB patients. With regard to the pattern of EM-induced changes in neutrophi function, however, there is considerable controversy ; some investigators have indicated no substantial changes $^{8)}$, while others mentioned a reduction ${ }^{9)}$ or enhancement. It should be noted, however, that this reported reduction in neutrophil function could only be demonstrated when neutrophils were treated at a very high concentrations of EM $(10 \mu \mathrm{g} / \mathrm{ml})$, above the therapeutic dose. Serum concentrations of EM in DPB patients under "small-dose and long-term" therapy were demonstrated to range from 0.5 to $1.0 \mu \mathrm{g} / \mathrm{ml}$. Therefore, it is unlikely that EM benefits the outcome of DPB patients by acting directly on neutrophils and changing their functions. Jo and colleagues $^{10)}$ reported the enhancement of macrophage function induced by EM at clinically achievable low concentrations ( 0.04 to $0.2 \mu \mathrm{g} / \mathrm{ml}$ ). Consequently, we investigated whether EM modifies the neutrophil function at concentrations of $1.0 \mu \mathrm{g} / \mathrm{ml}$ and below. We observed the effect of a 14membered ring, 15-membered ring and 16-membered ring macrolide EM, AZM and RKM, respectively) on neutrophil function in terms of active oxgen generation and chemotactic activity. From clinical observations, both EM and AZM has already been shown to be effective in treatment of DPB patients whereas RKM is ineffective. The present in vitro study demonstrated that both EM and AZM reduced DCFH-DA-determined active oxygen generation by neutrophils at both lower and higher concentrations $(0.1$ and $0.5 \mu \mathrm{g} / \mathrm{ml}, 10.0$ and $20.0 \mu \mathrm{g} / \mathrm{ml})$, and that the two agents inhibited neutrophil chemotaxis at a wide range of concentrations ( 0.1 to $20.0 \mu \mathrm{g} / \mathrm{ml})$. In contrast, RKM showed no significant inhibition of active oxygen generation, and showed inhibition of neutrophil chemotaxis only at extremely high concentrations $(10.0$ and $20.0 \mu \mathrm{g} / \mathrm{ml})$ which were far above those which were achievable at clinical doses.

For the determination of active oxygen generation the DCFH-DA method, which detects mainly hydrogen peroxide molecules ${ }^{5,6}$, was found to be more sensitive than the cytochrome $\mathrm{C}$ method which detects mainly superoxide anions. Another reason for the superiority of the DCFH-DA method in measurement of active oxygen generation may be that is employs whose blood as the test sample, whereas cytochrome $\mathrm{C}$ method requires partially purified neutrophil preparations in which the viability of neutrophils was lower than in whole blood. Therfore, by employing the former method, the effect of EM on neutrophil functions can be determined more accurately and with higher sensitivity. Furthermore PMA was used in the present study as an agent which stimulates active oxygen generation, directly activates protein kinase $\mathrm{C}$ and induces active oxygen generation independently from extracellular $\mathrm{Ca}^{2+}$-mediated stimulation ${ }^{11,12)}$. The present result demonstrating that the PMA-stimulated but not $\mathrm{Ca}^{2+}$-dependent generation of active oxygen is inhibited by EM, is in contrast ot previous reprots, which demonstrated that the inhibitory effect of EM on neutrophil function was $\mathrm{Ca}^{2+}$-mediated ${ }^{9,13,14)}$. 
In the present study, FMLP-stimulated neutrophil chemotaxis was also inhibited by EM. Our results strongly suggested that both EM and AZM inhibit the activation of neutrophils at the point in the active oxygen generating pathway after protein kinase $\mathrm{C}$ acts.

As stated previously, there is considerable controversy concerning the potency of macrolides in modulating neutrophil functions. It seems the consensus today is that macrolides can modulate the neutrophil functions only at extremely high concentrations which are not achievable at therapeutic doses and hence that they act indirectly on neutrophils by suppressing first the production and release of neutrophil-activating substances such as IL-8, LTB4 and C5a from other cells. The present study, however, clearly demonstrated that some macrolides are able to directly inhibit the active oxygen generation and chemotaxis of neutrophils even at low concentrations which are easily achieved at therapeutic doses. Furthermore, the inhibitory effect on neutrophil functions was demonstrated clearly in the in vitro system with either EM or AZM, a both of which are known to be effective in treatment of DPB patients. In contrast, in vitro the clinically ineffective RKM had no inhibition effect in this assay.

In conclusion, the direct in vitro effect of EM and AZM on neutrophil function, may be responsible at least in part, for the therapeutic efficacy of these 14-membered and 15-membered ring macrolides in the treatment of DPB patients.

\section{Acknowledgements}

The author thanks Dr. J. Honda for valuable advice and technical assistance. The author also thanks Prof. Kotaro Oizumi, and his staff (Department of Medicine Kurume University School of Medicine) for valuable suggestions throughout this study.

\section{References}

1) Kodoh $\mathrm{S}$, Uetake $\mathrm{T}$, Hagiwara $\mathrm{K}$, et al.: Clinical effect of low-dose long-term erythromycin chemotherapy on diffuse panbronchiolitis. J Jpn Thorac Dis 1987; 25: 632-642.

2) Ichikawa Y, Koga H, Tanaka M, Nakamura M, Tokunaga N \& Kaji M: Neutrophilia in bronchoalveolar lavage fluid of diffuse panbronchiolitis.Chest 1990; 98: 917-923.

3) Bringham KL: Role of free radicals in lung injury. Chest 1986; 89: 859-863.

4) Ichikawa $\mathrm{Y}$, Ninomiya H, Koga H, et al.: Erythromycin reduce neutrophils and neutrophil-derived elastolytic-like activity in the lower resriratory tract of bronchiolitis patients. Am Rev Respir Dis 1992; 146: 196-203.

5) Bass DA, Parce JW, Szejda P, Seeds MC \& Thomas M: Flow cytometric studies of oxidative product formation by neutrophils. J of Immuno, 1985; 130: 1910-1917.

6) Taga K, Seki H \& Taniguchi N: Flow cytometric evaluation of neutrophil functions on microquantities of whole blood. Clin Immunol 1985; 17: 490-498.

7) Kadota J, Sakito O, Kohno S et al: A mechanism of erythromycin treatment in patients with diffuse panbronchiolitis. Am Rev Respir 1993; 147: 153-159.

8) Honjo M, Fujita I, Hamasaki Y, Miyazaki M \& Miyazaki S: Erythromycin does not directly affect neutrophil functions. Chest 1994; 105: 520-523.

9) Hirata T, Matsunabe S, Matsui Y, Kado M, Kino M \& Oshima S: Effect of erythromycin on the generation of neutrophil chemiluminescence in vitro. J Jpn Thorac Dis 1990; 28: 1066-1071.

10) Guang XU, Fujita J, Negayama K et al: Effect of erythromycin on macrophage function. J Jpn Assoc Infect Dis 1995; 69: 590-596.

11) Nishizaki Y: The role of protein kinase $C$ in cell surface signal transduction and tumor promotion. Nature 1984; 308: 693-698.

12) DeChatelet LR, Shirley PS \& Johnston RJr: Effect of phorbol myristate acetate on the oxydative metabolism of human polymorphonuculear leukocytes. Blood 1976; 47: 545-554.

13) Andeson R: Erythromycin and roxithromycin potentiate human neutrophil locomotion in vitro by inhibition of leukoattractant-activated superoxide generation and autooxidation. J Infect Dises 1989; 159: 966-973.

14) Mitsuyama T, Tanaka T, Hidaka K, Abe M \& Hara N: Inhibition by erythromycin of superoxide anion production by human polymorphonucular leukocytes through the action of cyclic AMP-dependent protein kinase. Respiration, 1995; 62: 269-273. 


\title{
マクロライド系抗生物質の好中球機能に対する影響
}

\author{
久留米大学第一内科 \\ 杉原 栄一郎
}

\begin{abstract}
要旨
近年，びまん性沉細気管支炎（DPB）を含む難 治性下気道感染症において, マクロライド系抗生 剂の有効性が報告されているが，その作用機序に ついては未だ明らかにされていない.今回我々は 14員環のエリスロマイシン (EM)，15員環のアジ スロマイシン (AZM)，16員環のロキタマイシン (RKM) の好中球活性酸素産生及び好中球遊走能 に及ぼす影響を観察した。活性酸素は, DCFH-DA 法, cytochrome C 法の 2 通りの方法で行い, 遊走

に有効と言われている EM, AZM は, 未梢血好中 球活性酸素, 遊走能を有意に抑制し, この抑制効 果は, 0.1 か $0.5 \mu \mathrm{g} / \mathrm{ml}$ の臨床的に到達可能な低 い血中濃度で認められた。臨床的に無効と言われ ている RKM は, 好中球活性酵素, 遊走能に対し て同じ低い濃度で抑制効果を認めなかった。以上 の結果より $\mathrm{EM}, \mathrm{AZM}$ の好中球機能抑制効果が DPB に対する有効性の一因である可能性が示唆 された。
\end{abstract} 能は Boyden-chamber 法を用いて行った。臨床的 